Burnt and Blossoming: Material Mysticism in Trilogy and Four Quartets

Dr. Elizabeth Anderson

Honorary Research Associate

Centre for the Study of Literature, Theology and the Arts

Theology and Religious Studies

No. 4 The Square

University of Glasgow

Glasgow, G12 8QQ

UK

email: s.elizabeth.anderson@gmail.com

mobile: $+44(0) 7766711006$

home: +44 (0)1414235768 


\title{
Burnt and Blossoming: \\ Material Mysticism in Trilogy and Four Quartets
}

\begin{abstract}
:
This paper brings two WWII poems into dialogue: H.D.'s Trilogy and Eliot's Four Quartets. Both poems express a creative response to the destruction of war. My reading of Trilogy suggests a material mysticism in which vision and renewal are situated within the natural world, rituals and bodily experience. Bringing this understanding of mysticism to bear on Four Quartets reveals tension between transcendence and materiality. For Eliot, redemption comes through time and location, while for H.D., redemption lies within material particularity. Four Quartets oscillates between an apophatic discourse that seeks to transcend desire and history and an emphasis on material particularities.
\end{abstract}

Bio:

Elizabeth Anderson completed her $\mathrm{PhD}$ in Literature, Theology and the Arts and English Literature at the University of Glasgow in 2011. She is currently an honorary research associate the Centre for Literature, Theology and the Arts. Her research involves twentieth-century women's writing, feminist theory and feminist theology. She has published articles in Women: a cultural review and Literature and Theology and is co-editor of Memory, Mourning and Landscape, published by Rodopi, 2010. Her monograph H.D. and Modernist Religious Imagination is forthcoming from Continuum in 2013. 


\section{Burnt and Blossoming: \\ Material Mysticism in Trilogy and Four Quartets}

In 1943, Osbert and Edith Sitwell organised a gala poetry reading in London, intended to promote the arts during war time. ${ }^{1}$ The American expatriate writer H.D. read a poem proclaiming the endurance of Ancient Wisdom, personified as a woman in blue, and the ability of her devotees to be vanquished and yet retain agency:

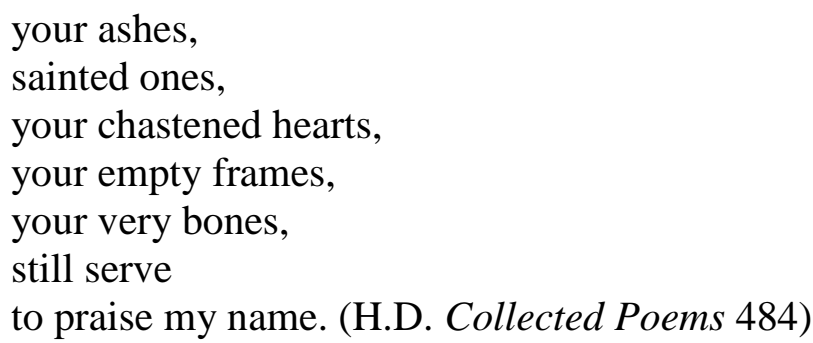

Here H.D. suggests a mingling of sacred and profane, material reality and transcendence. At the same event, T.S. Eliot read the section of The Wasteland that ends with the words, "London Bridge is falling down" (Bryher 84). Both poets also engaged in larger projects comprising a creative response to the destruction of war. ${ }^{2}$ Their major poetic works of the Second World War, Trilogy and Four Quartets, both use themes of loss, renewal and redemption to explore and complicate a dynamic relationship between the material and the spiritual. Despite the similarities of the poems' composition, setting and themes, they are rarely read together critically. ${ }^{3}$ I suggest that bringing Trilogy and Four Quartets into dialogue yields productive readings of both poems that demonstrate the breadth and complexity of the mystical imaginary in late modernist poetry.

Both Trilogy and Four Quartets are rife with references to bombed buildings, loss and ghostly presences. At the same time, images relating to new life, growth and spiritual renewal also proliferate in the texts. Although very different in style, both poems can be read as modernist epics, detailing a spiritual quest that seeks regeneration and redemption. Both Eliot 
and H.D. draw upon religious sources and use similar imagery to develop their creative visions. However, the effects of such sources and images are significantly different, reflecting the poets' differing religious and literary commitments.

Numerous critics have commented on the mystical elements of Four Quartets, with particular attention to apophatic mysticism, or negative theology. ${ }^{4}$ Put simply, apophasis is the negation of all attributes of God; its ultimate expression is silence. Readings of the Quartets' mysticism have located the primary tension between human desire and divine love, between historical or personal time and eternity, or between apophatic discourse and an affirmative, universalizing metaphysics (Donoghue "On 'Burnt Norton"” 15; Kearns “Negative Theology" 131-57; Levenson 158-78; Moody 176-77). However, reading Four Quartets alongside Trilogy indicates a different, albeit related, set of tensions. My reading of Trilogy finds vision and renewal situated within the natural world, rituals and bodily experience; thus the poem constructs an imaginative material mysticism. Bringing this understanding of mysticism to bear on Four Quartets reveals an axis of tension between apophatic transcendence and material particularity. For Eliot, redemption comes through time and location, while for H.D., redemption is discovered within material particularity. This is, of course, a rather simplified view of the texts. Rather than beginning with the earlier, and more well-known, Four Quartets, I begin with Trilogy, in order to elaborate a way of reading which will inform my approach to Eliot (although I assume that Four Quartets is a popular enough text to permit illuminating comparisons in the course of my reading of Trilogy). Turning then to Four Quartets, I trace Eliot's negative asceticism which is oriented towards transcendence, and finally turn to consider the evidence of an intractable materiality in Four Quartets that refuses such a trajectory. 


\section{H.D.'s material mysticism}

Trilogy opens with reference to the London Blitz, establishing a community of narrator and readers in the face of destruction: "An incident here and there, / and rails gone (for guns) / from your (and my) old town square" (H.D. Walls 1:1-3). ${ }^{5}$ H.D. goes on to connect contemporary London and ancient Egypt and suggests not only a historical palimpsest but a spiritual one: "still the Luxor bee, chick and hare / pursue unalterable purpose / . . / they continue to prophesy / from the stone papyrus" (H.D. Walls 1:5-9). She mobilizes symbols of regeneration and archaeological remains to suggest that potential for discovery and renewal lies even in the midst of bombed buildings:

there, as here, ruin opens the tomb, the temple; enter, there as here, there are no doors: ..................... through our desolation, thoughts stir, inspiration stalks us through gloom. (H.D. Walls 1:10-21)

In these opening passages we see the central concern of Trilogy - the response of a poet to the physical, psychic and spiritual desolation of her time - as well as the strategy she will employ to address this concern, the invocation of ancient wisdom allied with contemporary inspiration. Thus H.D. establishes a visionary consciousness that is both personal and (potentially) communal, and which she will develop through the subsequent volumes of Trilogy.

Like T. S. Eliot, H.D. draws upon religious traditions to inform her writing. However, she seeks the transgression of spiritual boundaries rather than the renewal of orthodox faith. ${ }^{6}$ The beginning of Trilogy indicates the syncretism that is a feature of H.D.'s poetry. Drawing upon a diversity of religious sources - Christianity, Egyptian, Greek and Roman cults, hermeticism, alchemy and astrology - H.D. gives her own idiosyncratic interpretation to her source material. She weaves together a diversity of references and images to develop an 
understanding of mysticism that resists the binary of transcendence and immanence, locating the sacred within the material world but without dissipating the mystery that usually inheres in discourses of transcendence. In her perceptive reading of H.D.'s war writing, Madelyn Detloff argues that Four Quartets and Trilogy are alike in their redemptive arc and their redescription of war's destruction as a triumphant narrative that elides real loss (Detloff 80-87). However, images such as the half-burnt, half-blossoming tree are a sign of irreducible loss that remains an insistent presence in the poem, as the presence of multiple religious traditions in Trilogy continue to trouble any singularly Christian reading. In Trilogy, the presence of the sacred within the material suggests that, for H.D., it is this world that is the location of loss, mourning and renewal, not an otherworldly transcendent teleology.

Alicia Ostriker and Adalaide Morris argue that H.D. is primarily a "visionary poet" interested in "sacred realities" (Ostriker 8; Morris "Signaling" 130-31). In addition to her religious syncretism, H.D. also elides the distinctions between art, vision and religion. Each of these becomes both a catalyst for and a way of interpreting the others. An alchemical ritual gives rise to mystical contemplation, while elsewhere, alchemy is aligned with writing. Mystical visions - of a Lady, a tree -culminate in the final vision of the poem, when the sage Kaspar sees the Hesperides, Atlantis and Paradise and remembers the adoration of the Magi at the first Epiphany. The guiding purpose of these visions is healing, growth and transformation. Images of renewal, rebirth and resurrection proliferate across Trilogy: bees; blossoming trees; a pearl in its shell; a worm becoming chrysalis becoming butterfly; the staff of Hermes that symbolizes healing and wisdom and also the death and resurrection indicated by the serpent that winds around the staff. H.D.'s poetry suggests a material mysticism as she locates transcendence within these organic images.

The material forms a significant element of the more striking visions in Trilogy. The poet marks how regeneration may come from ruin in the image of blossoms creating a sacred space: 
the lane is empty but the levelled wall

is purple as with purple spread upon an altar,

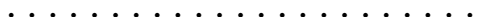

where, Uriel, we pause to give

thanks that we rise again from death and live. (H.D. Angels 7:6-12)

This image is later reconfigured in the vision of a "charred tree ... burnt and stricken to the heart" (H.D. Angels 19:12-13). In an image strongly reminiscent of Eliot's fire and rose, this charred tree is also in flower. The burnt yet blossoming tree suggests redemption, divinity, inspiration. Here H.D. brings together destruction and renewal and declares that God may be found not only in the blossom, but also in the charred remains. This is a vision that draws in poet, companions and reader, referencing the ritual of the Eucharist:

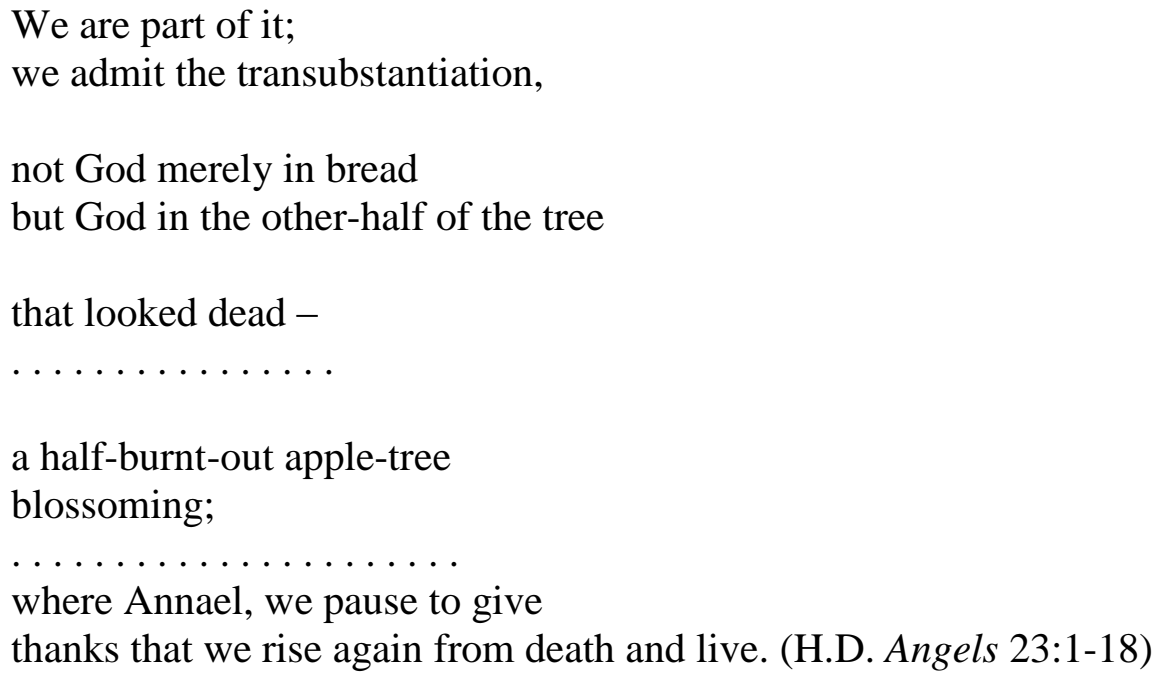

The repetition within and between these two sections, the pairing of the angels Uriel and Annael, and the giving of thanks in a sacred space indicate a ritual within the poetry itself. In referencing the Christian Eucharist, H.D. signals her own ritualizing activity which extends the sacramental into a new space. In this vision of flowers and a tree in blossom amidst ruins, the poet and her community are transformed. Yet for all its divinity, H.D. resists a transcendent reading. She emphasizes its mundane, everyday aspects: "it was an ordinary tree / in an old garden-square" (H.D. Angels 20:13-14). The emphasis on materiality is maintained in one of the more esoteric rituals of Trilogy - an alchemical process.

As Morris notes, the process of distillation, transformation and birth of new forms is 
referenced repeatedly across Trilogy. From the metamorphosis of seed, shell and chrysalis, to the larger narratives of the poem which suggest transformation effected in the crucible of war, these transformations culminate in "[t]he ultimate, audacious hope . . . that [Trilogy] might itself carry and transmit a formula for regeneration" (Morris H.D. 's Cultural Poetics 115). Among the many strands of H.D.'s religious syncretism, hermeticism - the philosophy that underlies alchemy - provides a worldview that allows diverse elements to be brought together in the search for ancient wisdom and hidden knowledge. ${ }^{7}$ H.D. uses an alchemical ritual and the multiple interpretations enabled by hermeticism to explore the relationship between writing, materiality and the sacred.

Scholars of hermeticism are quick to point out the complexities and enigmas of this tradition. The proliferation of texts and the interweaving of secrecy and revelation make the history of hermeticism difficult to establish. Hermeticism is perhaps best characterized as a world-view marked by devotion to Hermes (god and sage) and ancient wisdom (both revealed and concealed); it is "a form of thought rather than a doctrine" (Faivre 65). The role of Hermes in Western culture is varied: the messenger of the gods; the founder of cities; the creator of writing, the arts and alchemy; the bearer of souls to the after world; trickster; thief. ${ }^{8}$ $\mathrm{He}$ is the patron of "poets, orators, thieves" (H.D. Angels 1:6). His thievery involves returning hidden treasures to circulation; or relays of knowledge (Faivre 15, 21). Like Gnosticism and related traditions, hermeticism indicates that salvation comes through knowledge. However, this knowledge is not acquired through rational pursuits alone, but also through mystical experiences that come through disciplined study and practice. The hermeticist seeks "gnosis, or direct awareness of the Divine attained through ... ritual initiation" (D. P. Tryphonopoulos xii). Hermeticism suggests that the divine is the soul of the world, and thus is hidden and revealed in creation (Tuveson xiv). Both divinity and the created world are mutually unfolding, dynamic rather than static: "even the divine image is 
not complete" (Tuveson 57). At the heart of alchemy is the hermeticist understanding of all matter as alive, and in dynamic relation.

In the alchemical ritual in Tribute to the Angels words (myrrh and its cognates) become a jewel:

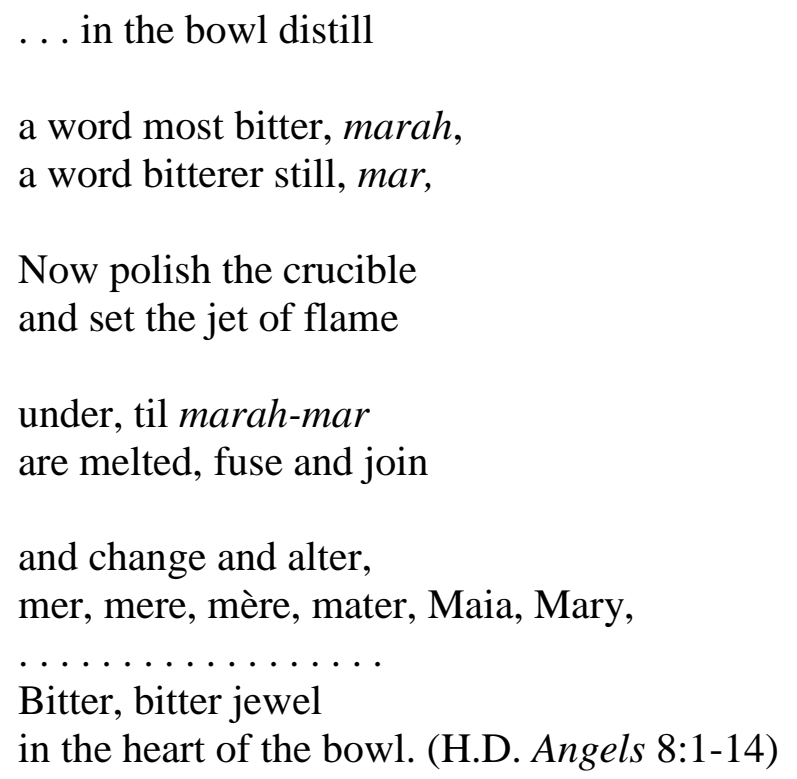

The alchemical ritual presents a twist on the earlier metaphors of transformation; this ritual partakes of both natural and cultural processes. H.D. puts an idiosyncratic twist on alchemy by constructing a process which distils not metals, but words. However, material transformation is not discarded. She draws a correspondence between the poet and the alchemist when the distillation of words converts into matter and back into language. The word/jewel suggests both the materiality of language and the ability of matter to signify, thus allowing H.D. to align hermetic philosophy and alchemy with artistic practice.

The final section of Tribute to the Angels returns to the alchemical jewel and in a further transforming process turns jewel to flowers to an enigmatic face which may be of the Lady who appears earlier in Angels, or of the Christ child who will appear again at the end of Trilogy:

we find not ashes, not ash-of-rose, not a tall vase and a staff of lilies, 
not vas spiritual,

not rosa mystica even,

but a luster of garden-pinks

or a face like a Christmas-rose. (H.D. Angels 43:15-22)

As Cyrena Pondrom argues, this can be read as a direct response to the ashes of roses, devotion to the Virgin Mary and purifying fire in Four Quartets (Pondrom 136). What we find emphasized here is an alternative to Catholic ritual and traditional Marian symbols. Instead, common flowers and references to incarnation emphasize the interplay of ordinary materiality, Christian spirituality, and alchemical ritual.

The final vision in Trilogy is also grounded in the material. A glimpse of the wild, sensuous hair of Mary Magdalene inspires Kaspar's vision. Kasper is an enigmatic figure in the poem, the wise man of the Epiphany, magician, alchemist (Mary and Kaspar also mark the syncretist interplay between alchemical hermeticism and Christianity). Mary and Kaspar are aligned through the two jars of myrrh which form the focus of the final sections of Trilogy. The first is Kaspar's gift to the Christ child. The second jar is given to Mary by Kaspar; this is the ointment she uses to anoint Jesus before the crucifixion, in a re-telling of the Biblical narrative in which an unnamed woman - traditionally read as Mary Magdalene pours perfume over Jesus's feet and wipes them with her hair.

The image of myrrh and, most significantly, its fragrance, re-occurs throughout Trilogy. Fragrance is uncontained by the ritual and drifts through the poem, drawing together the alchemical ritual and the war-torn city that is Trilogy's location and frame. Morris reminds us that alchemy itself is a frame for the poem as the entirety of Trilogy is contained in the crucible of war (Morris "Signaling" 110-13). The regeneration represented by the alchemical jewel corresponds to the renewal of bombed London: "tell me, in what other city / will you find the may-tree . . . like our jewel in the crucible?” (H.D. Angels 17:17-20) By analogy, the blossoming may-tree takes the elixir of life into the streets; the fragrance of 
jewel and tree consecrate the city as a sacred space: "no temple / but everywhere" (H.D. Angels 18:1-4).

Myrrh brings together the fragrance of the blossoming tree, the linguistic alchemical ritual and Mary herself. In the figure of Mary, H.D. draws a connection between the alchemical ritual that transmutes words and substances, with the personal transformation also sought by alchemists. In anointing Christ before the crucifixion with myrrh, Mary becomes the alchemist who prepares the way for the transformation of resurrection. However, Mary herself is linked with myrhh:

I am Mary - O, there are Mary's a-plenty, (though I am Mara, bitter) I shall be Mary-myrrh

I am Mary, the incense-flower of the incense-tree, myself worshipping, weeping, shall be changed to myrrh.

(H.D. Rod 16:9-10, 19:1-2)

Here Mary indicates that her identity mirrors the alchemical ritual in which the word "marah" becomes "Mary." She participates in the alchemical process as the poet longs to do. Throughout Trilogy, fragrance indicates life, renewal and transformation; the visionary consciousness that enables such renewal is grounded in the material world. Visions and dreams meet the blossoms of London's gardens in springtime.

H.D. suggests that the alchemical rituals in Trilogy work in a number of directions simultaneously. The mutability of myrrh - indicated by its drifting fragrance - reveals hermetic dynamism. Myrrh is an image for the divine life that permeates the universe. H.D. aligns fragrance with a variety of visions, rituals and experiences throughout the poem; it indicates bitterness and sweetness, death and resurrection, sensory experience and imagination, healing and transformation.

The images from the natural world that appear frequently in Trilogy - flowers, shells, pearls, a chrysalis - are correlated to the body from H.D.'s earliest poetry. By linking the body with images in the natural world that signify growth, transformation and decay, H.D. 
presents a body that is constantly opening and changing. These particular images embed the spiritual in bodily experience, adding another dimension to the materiality of language in H.D.'s poetics. Throughout her writing, she emphasises both the sensory content of visionary experiences and the sensory experiences that lead to vision; the alchemical jewel not only links language to material object, but also connects the poetic image with the body. The jewel itself is alive; already the product of ritual, subject of transformation and object of contemplation, the jewel suggests that the sacred may be found in the body.

The experience of embodiment in Trilogy is frequently figured as traumatic (Graham 299-319; Laity 170-82). Amy Hollywood argues that attempts to transcend bodily trauma and loss indicate a refusal to come to terms with mortality. She suggests that mysticism provides resources for "thinking the body otherwise, as the site of possibility and limitation, pleasure and suffering, natality and death" (Hollywood Sensible Ecstasy 186). H.D.'s view of the body as mutable and multiple makes space for regeneration to be held alongside traumatic bodily experience. From its dramatic opening, Trilogy compresses abjection and survival:

the bone frame was made for no such shock knit within terror, yet the skeleton stood up to it :

the flesh? it was melted away, the heart burnt out, dead ember, tendons, muscles shattered, outer husk dismembered,

yet the frame held. (H.D. Walls 1:43-9)

The complexity, ambiguity and dynamism of embodiment are evident in the unfolding progression of myrrh. In Trilogy, pleasure and pain are both held within this resonant word. The bitterness of the word marah - that becomes the bitter jewel - is linked linguistically to myrrh - a substance associated with death and burial as well as incense and perfume. This sensual, illusive element, fragrance, holds together bodily experiences of beauty and bitterness, birth and death. Through H.D.'s work we see "the pleasures and pains of the 
(speaking) body." 9 Presented as fragmentary or whole, the site of ecstasy, desire and passion, or disruption, loss and grief, for H.D. the body is expressive of the multiplicity of human experience.

Kaspar's vision is rooted in the material; inspired by Mary's hair, it is related to embodiment, and it also touches on issues of place, time and history. He sees a world within "a grain, a flaw, or a speck of light" (H.D. $\operatorname{Rod} 30: 6-8)$. This point is in contrast with the still point that for Eliot is the "centre of the turning world" (Eliot 5); Kaspar's speck is a point-inprocess, leading to movement and change. Through his vision, H.D. reconfigures her favoured image for history - the palimpsest - as a spiral: "spiral upon spiral of the shell / of memory that yet connects us / with the drowned cities of pre-history" (H.D. Rod 33:17-19). Here individual memory and history are not so much transcended as densely layered. Moreover, Morris notes that the complex weaving of past and present aligns secular and sacred dates, foregrounding the presence of history. She cites the composition dates included at the end of Tribute to the Angels and The Flowering of the Rod (May 17-31, 1944 and December, 18-31, 1944 respectively), the time and place included in the dedication of The Walls Do Not Fall, and the climax of the final poem, the Feast of the Epiphany, or 6 January (Morris "Signaling" 133). The final dates in particular emphasise process, the turn from the old year to the new.

Writing forms yet another connection between spiritual and material in Trilogy. H.D. asserts poetry's significance as a response to war's destruction, albeit somewhat bitterly:

Thoth, Hermes, the stylus, the palette, the pen, the quill endure,

though our books are a floor of smouldering ash under our feet; though the burning of books remains the most perverse gesture folio, manuscript, old parchment 
will do for cartridge cases. (H.D. Walls 9:1-12)

Allied with the stylus of Thoth and Hermes and later with the Lady's "blank book of the new," writing here is configured as a sacred activity in defiance of those who would argue that the best use for paper is cartridge cases. Unlike the "illegible stone" in Four Quartets, in Trilogy, stones speak, as hieroglyphics "continue to prophesy / from the stone papyrus" (Eliot 42; H.D. Walls 1:8-9).

Throughout Trilogy, H.D. emphasizes the physicality of writing as a practice, hieroglyphics etched in stone bear witness to the tangible density of language. Yet the ritualized language surrounding this emphasis on the material suggests that this is an activity which sacralises the mundane. This is made explicit in the alchemy of word-becoming-jewel. The fragrance of the word/jewel forges a connection between language and the poems' sensory emphasis, while alchemy itself suggests the dynamism that words have for H.D.; language is slippage, movement and transformation: "Let us substitute / enchantment for sentiment, / . . / prepare papyrus or parchment, / offer incense to Thoth" (H.D. Walls 35:18). Writing also produces a physical object that remains after the performance has been completed. This object in turn mobilizes the practice of reading. In Trilogy, the poet invites the reader to participate in its textual rituals.

Through the exploration of ritual, embodiment, and writing as both practice and product, Trilogy seeks to embrace, rather than transcend the material world; thus elaborating a mysticism that refuses absolute distinctions. H.D.'s mysticism locates divine mystery and redemption within the folds and interstices of materiality. Foregrounding this understanding of mysticism, I now turn to the dynamic tension between the transcendent and the irreducible particular in Four Quartets.

\section{The question of transcendence in Four Quartets}

Rather than a flowering tree in a city square, Eliot gives us a provisional rose garden. Doubly 
provisional, in fact, for this is the memory of a might-have-been: "Footfalls echo in the memory / down the passage which we did not take / Towards the door we never opened" (Eliot 3). The first section of Burnt Norton is rife with ghostly presences in the never-visited garden: the laughter of hidden children, unheard music and an empty pool. In this place which is not a place, the play of light initiates a moment of mystical vision: the pool fills and a lotus rises. Presence replaces absence, briefly.

To elaborate on my previous definition, apophatic theology argues that God is completely other to anything that could be said or known about God. ${ }^{10}$ Apophasis is the process of "unsaying" everything that has been said about God. It is the via negativa, the way of ignorance, of un-knowing. Language collapses, leaving only silence. ${ }^{11}$ Some theologians contrast apophasis - the negation of images - with cataphasis - the affirmation of images. Others claim that cataphasis itself is subsumed within apophasis. Denys Turner argues that for classical negative theology, what is required is to say all things of God, negate all of these things and then go on to negate the distinction between them (Turner 19-22). Apophasis is then the destabilization of language that is accomplished by this final negation (Turner 22). ${ }^{12}$ For mystics such as John of the Cross, apophatic theology becomes a spiritual discipline in the ascetic negation of all sensation. The goal is the stripping away of all things, both temporal and spiritual, and transcendent union with the ineffable silence of God. In Four Quartets we see a demonstration of this understanding of negative theology. The juxtaposition of positive and negative ways through the poem eventually yields to a dominant apophatic discourse.

Cleo McNelly Kearns describes the primary tension in Four Quartets as the attempt to hold together the apophatic and cataphatic, marked by the assertion 'the way up is the way down'. Kearns suggests that "the way down is the way of asceticism and abstraction, while the way up is the way of erotic experience, metaphor and imagination" (Kearns "Negative 
Theology" 132). ${ }^{13}$ Furthermore, she argues that the positive way, ascending towards a contemplation of the whole - tends towards a universalizing metaphysics - whereas the apophatic negations reveal the complexities, limitations and deconstructive tendencies of language. However, I argue that the primary tension in Four Quartets is between a negative way that seeks to transcend desire, history and place in an unsaying of sensory experience, and an emphasis on material particularities expressed in image and metaphor.

The intricacies of the tension between Eliot's apophatic discourse and material images are mapped out in numerous dialectical passages across Four Quartets. In pondering the provisional rose garden, Eliot suggests the significance of time for memory and experience of place:

But only in time can the moment in the rose-garden, The moment in the arbour where the rain beat, The moment in the draughty church at smokefall Be remembered; involved with past and future. (Eliot 6)

Yet from these evocative invocations of particular places, Eliot moves into the abstract, privileging the negation of what he has just asserted: "Only through time time is conquered" (Eliot 6). As soon as places are called to mind, the poet reverses, calling for the memories of smokefall and falling rain to be obliterated. Eliot follows John of the Cross; for both poet and mystic: "the negative way not only takes precedence over any positive one, but finally absorbs it" (Wolosky 19). Allusions to the writings of John of the Cross are most evident in East Coker where Eliot writes out his own negative way:

I said to my soul, be still, and wait without hope For hope would be hope for the wrong thing; wait without love For love would be love of the wrong thing; there is yet faith But the faith and the love and the hope are all in the waiting.

To arrive where you are, to get from where you are not, You must go by a way wherein there is no ecstasy. In order to arrive at what you do not know You must go by a way which is the way of ignorance. In order to possess what you do not possess You must go by the way of dispossession. (Eliot 17) 
As Wolosky goes on to point out, "the poem's positive visions are also framed in and through negation:" Little Gidding's midwinter spring, whose beauty makes the "soul's sap quiver" results in the "unimaginable / Zero summer" (Eliot 35). ${ }^{14}$

Eliot's Little Gidding is the object of a provisional pilgrimage, hedged about with 'if's' and adorned with blossom, much like H.D.'s vision of springtime London in the Blitz:

If you came this way,

Taking the route you would be likely to take

From the place you would be likely to come from,

If you came this way in may time, you would find the hedges

White again, in May, with voluptuary sweetness.

(Eliot 35, emphasis mine)

Yet this provisionality gives way to a prescribed asceticism which disregards the particularities of time and season:

If you came this way,

Taking any route, starting from anywhere,

At any time or at any season,

It would always be the same: you would have to put off

Sense and notion. (Eliot 36)

This erases the particular features of individual seasons: without the senses, the sweetness of the blooming hedges is rendered meaningless. The fragrance of blossom does not drift through the poems, but is contained and negated.

Little Gidding makes direct reference to the apocalyptic destruction of war: "the dark dove with the flickering tongue" referencing a German bomber (Eliot 37). Eliot sets up a parallel between this 'dark dove' and the Holy Spirit (traditionally symbolized with a dove) who descends with a "refining fire" at Pentecost (Eliot 39) and suggests that the reader must choose between the two:

The dove descending breaks the air

With flame of incandescent terror

Of which the tongues declare

The one discharge from sin and error.

The only hope, or else despair

Lies in the choice of pyre or pyre - 
To be redeemed from fire by fire. (Eliot 41)

The way of dispossession leads through the fires of purgation to a final mystical unity in which "the fire and the rose are one" (Eliot 43). As H.D. does in Trilogy, Eliot here presents a vision of redemption springing from the midst of destruction, although we may be uncomfortable with the similarity in Eliot's descriptions of the Holy Spirit and the destructive bomber. In drawing the fire of Pentecost and the machine of war so closely together, Eliot obliquely suggests that violent destruction is required for redemption. Like Detloff, Wolosky critiques this move towards transcendence, questioning how an otherworldly unity can be the "site for redemption of this world of change and difference ... of development and growth" (Wolosky 48). While I share this concern, I argue that the transcendence in Four Quartets is not as complete as the poet and critics may suggest. The paradoxical quality of Four Quartets lies in their description of experiences indicating both immanence and transcendence.

The place of the material is a vexed issue at the heart of Four Quartets. It could be argued that the material plays a crucial role in the quest for transcendence enacted in the poem. It cannot be denied that the pilgrimage to Little Gidding - a specific place - sets the stage for the poem's final eschatological vision. It is this place - "Now and in England" - that marks a sacred space, even, perhaps, a material mysticism (Eliot 36). But, as Alan Marshall points out, this rendering of England itself tends to move from the real to the ideal; arranged along "other places", the particular seems lost in abstraction (Marshall 94-107). Moreover, a deeper ambivalence is marked by the problem of the evasion of time. Wolosky points out that while the poet pursues detachment, "the values of utmost importance to those living in time, become interchangeable," if, as the poet declares: "History may be servitude / History may be freedom. See, now they vanish / The faces and places, with the self which, as it could, loved them, / To become renewed, transfigured, in another pattern" (Eliot 40). The possibility of transformation within history is lost; any transfiguration of these vanished faces leaves the 
problems of history unresolved (Wolosky 27). Neither can we ignore the influence of negative theology, John of the Cross and the way of dispossession, the reiterated moves towards abstraction.

Therefore, the Four Quartets strains towards a mysticism in which materiality is a subordinate, if necessary, route to transcendence, "only through time time is conquered" (Eliot 6). The conquering of time is still the goal, the material is invoked as a route to transcendence, not the location of divinity in the particularities of here and now. However, the text is more complicated than this argument suggests. For the remainder of this essay I wish to explore a reading of Four Quartets that goes against the grain, a reading that is opened up by H.D.'s material mysticism. Despite straining towards transcendence, Eliot's vision continues to collapse into the creative excess of the material. Traces of this alternative vision of the sacred may be seen from a number of perspectives: firstly, in the lingering traces of desire in the poem; secondly, in the poem's structure and the poet's preoccupation with language; and thirdly, in the sacred residue in material images.

Despite the poet's claim that "Desire is . . Not in itself desirable," desire is not entirely removed from the poem (Eliot 8). Most obviously, the repeated iterations of the word reinscribe desire even as the poet would negate it. More subtly, it is evident in the complicated metaphor of the final unity of the fire and the rose. Some readers see this as a transformation of human love into divine love, a transcendence of human desire (Moody 17577). This may be so, but the rose lingers as a powerful image; despite its transformation it reminds us of the earlier roses in the garden and the loss suggested by the ashes of burnt roses. The final unity is deferred to an unspecified future: "All manner of thing shall be well / When the tongues of flame are in-folded / Into the crowned knot of fire / And the fire and the rose are one" (Eliot 43, emphasis mine). However we may critique this vision, the poet's longing for this future moment is palpable and thus desire is inscribed in the poem's final 
lines.

Turning to structure and language, I argue that the circularity that Eliot repeatedly invokes undermines the trajectory of abstract ascent. Given a vision of perfected language in which "every phrase and sentence is an end and a beginning" it is hard not to take this as a reading strategy (Eliot 42). ${ }^{15}$ This strategy suggests that every material image in the poem can be taken as a beginning or an end, an intransigent point that resists its negation. Writing forms the subject of recurring meditations through the Four Quartets as it does in Trilogy. If Little Gidding provides an assertion of perfect writing - "every phrase / And sentence that is right," the previous quartets give Eliot space to lament the impossibility of expressing the ineffable in language (Eliot 42). He notes:

... Words strain,

Crack and sometimes break, under the burden,

Under the tension, slip, slide, perish,

Decay with imprecision, will not stay in place,

Will not stay still. (Eliot 8)

However, this breaking and sliding, this differentiation and movement is necessary for language to exist at all. Difference leads to creativity as well as decay. Poetry is dependent on differentiation and change.

The material, particular images provide an alternative to philosophical musings on language, history, and time. Eliot reminds us that most of us are not saints, himself included:

For most of us, there is only the unattended Moment, the moment in and out of time, The distraction fit, lost in a shaft of sunlight, The wild thyme unseen, or the winter lightening Or the waterfall, or music heard so deeply That it is not heard at all, but you are the music While the music lasts. (Eliot 30)

Eliot depends on the physical images of sunlight, wild thyme, lightening and a waterfall as the scaffolding for his apophatic mysticism. Yet before he asserts an abstract metaphysics of the conquering and reconciliation of past and future, he reveals the presence of God within 
these mundane yet blessed moments of sensual delight: "these are only hints and guesses ... The hint half guessed, the gift half understood, is / Incarnation" (Eliot 30). This understanding of divinity revealed in ordinary and particular experiences extends to images throughout the Quartets. "The moment in the arbour where the rain beat, / The moment in the draughty church at smokefall" insist on their significance in themselves, rather than as a route to transcendence (Eliot 6).

The closing section of Little Gidding presents us with images that are often neglected for the flashier "crowned knot of fire." I want to emphasize these few lines:

At the source of the longest river

The voice of the hidden waterfall

And the children in the apple-tree. (Eliot 43)

The "source of the longest river" can be read as a reference to an earthly paradise. ${ }^{16}$ Both the river and the "voice of the hidden waterfall" remind us of the divinity ascribed to a river in The Dry Salvages:

... I think that the river

Is a strong brown god...

..................

His rhythm was present in the nursery bedroom,

In the rank ailanthus of the April dooryard,

In the smell of grapes on the autumn table,

And the evening circle in the winter gaslight.

The river is within us. (Eliot 23)

Notwithstanding the primitivism (a problematic feature of modernism) implied by this characterization of the Mississippi, the divine is located within the mundane, although this time from a Pagan, rather than a Christian, perspective. ${ }^{17}$ The divine is revealed as immanent in the natural and the cultural, but this time it is not a church or the music and poetry of high culture but a more ordinary, domestic environment. In a rare moment in a poem which tends to locate the divine in a transcendent beyond we find divinity located within. Finally, "children in the apple-tree" re-invokes the laughter of hidden children in Burnt Norton's rose-garden. Surely the presence of children suggests the insistence, not only of history, but of history's claims upon us? The material mysticism 
offered by such images may be of more use to us than the language of negation and ascetic discipline. As much as the poet may wish to negate the traces of the material for a pure transcendent unity, the poetry remains mired with the "Garlic and sapphires in the mud," along with the rest of us (Eliot 4).

The question of use is not incidental here. There is a choric element in both Four Quartets and Trilogy; Eliot and H.D. frequently employ the first person plural - "we" and "us" (Gregory 124-25; Morris H.D.'s Cultural Poetics 135). The poems then become offerings and exhortations to a community, whether the intimate circle of initiates, "companions / of the flame" or the wider circle of Londoners coming together through the horrors of the Blitz, or even wider circle of future readers (H.D. Walls 13:25-26). Like a ritual, the poems are meant to be used; they offer the reader their visions of renewal, and invite the reader to participate in their open-ended, ongoing practice. They offer a passionate response to the question: what is the use of poetry in wartime? Rather than responding to war's destruction by transcending the historical and the material, Trilogy and Four Quartets attend to what is already present but overlooked - the blossoms, the ruins, the church at smokefall, children in the apple-tree. They provide a way of seeing the ordinary as radiant, saturated with the sacred.

\section{Works Cited}

Brock, Rita Nakashima, and Rebecca Ann Parker. Saving Paradise: How Christianity Traded Love of This World for Crucifixion and Empire. Boston: Beacon Press, 2008.

Bryher. The Days of Mars: A Memoir 1940-1946. London: Calder \& Boyars, 1972.

Bynum, Caroline Walker. Fragmentation and Redemption: Essays on Gender and the Human Body in Medieval Religion. New York: Zone Books, 1992.

Chisholm, Dianne. H.D. 's Freudian Poetics: Psychoanalysis in Translation. Ithaca, NY and London: Cornell University Press, 1992. 
Detloff, Madelyn. The Persistence of Modernism: Loss and Mourning in the Twentieth Century. Cambridge and New York: Cambridge University Press, 2009.

Donoghue, Denis. “On 'Burnt Norton'." Words in Time: New Essays on Eliot's Four Quartets. Ed. Edward Lobb. London: The Athlone Press, 1993. 1-19.

---. “T. S. Eliot's Quartets: A New Reading (1965).” T. S. Eliot: A Selection of Critical Essays. Ed. B. Bergonzi. London, 1969. 212-36.

Eliot, T. S. Four Quartets. 1944. London: Faber and Faber, 2001.

Faivre, Antoine. The Eternal Hermes. Trans. Joscelyn Godwin. Grand Rapids, MI: Phanes Press, 1995.

Foster, Paul. The Golden Lotus: Buddhist Influence in T. S. Eliot's Four Quartets. Lewes, Sussex: The Book Guild, 1998.

Friedman, Susan Stanford. Psyche Reborn: The Emergence of H.D. Bloomington: Indiana University Press, 1981.

Gardner, Helen. The Art of T. S. Eliot. London: The Cresset Press, 1949.

Graham, Sarah H. S. “Falling Walls: Trauma and Testimony in H.D.'s Trilogy.” English 56. Autumn (2007): 299-319.

Gregory, Eileen. H.D. and Hellenism: Classic Lines. Cambridge: Cambridge University Press, 1997.

H.D. Collected Poems 1912-1944. Ed. Louis L. Martz. New York: New Directions, 1983.

---. The Flowering of the Rod. 1946. Trilogy. New York: New Directions, 1998.

---. Tribute to the Angels. 1945. Trilogy. New York: New Directions, 1998.

---. The Walls Do Not Fall. 1944. Trilogy. New York: New Directions, 1998.

Hay, Eloise Knapp. T. S. Eliot's Negative Way. London: Harvard University Press, 1982.

Hollywood, Amy. Sensible Ecstasy: Mysticism, Sexual Difference, and the Demands of History. Chicago and London: The University of Chicago Press, 2002.

---. The Soul as Virgin Wife: Mechthild of Magdeburg, Marguerite Porete and Meister Eckhart. Notre Dame and London: University of Notre Dame Press, 1995.

Jantzen, Grace. Power, Gender and Christian Mysticism. Cambridge: Cambridge University Press, 1995.

Kearns, Cleo McNelly. "Negative Theology and Literary Discourse in Four Quartets: A Derridean Reading." Words in Time: New Essays on Eliot's Four Quartets. Ed. Edward Lobb. London: The Athlone Press, 1993. 131-57. 
---. T. S. Eliot and Indic Traditions: A Study in Poetry and Belief. Cambridge: Cambridge University Press, 1987.

Laity, Cassandra. H.D. and the Victorian Fin De Siècle: Gender, Modernism, Decadence. Cambridge: Cambridge University Press, 1996.

Levenson, Michael. "The End of Tradition and the Beginning of History." Words in Time: New Essays on Eliot's Four Quartets. Ed. Edward Lobb. London: The Athlone Press, 1993. 158-78.

Marshall, Alan. "“England and Nowhere"." The Cambridge Companion to T. S. Eliot. Ed. A. David Moody. Cambridge: Cambridge University Press, 1994. 94-107.

Materer, Timothy. Modernist Alchemy: Poetry and the Occult. Ithaca and London: Cornell University Press, 1995.

McIntosh, Mark A. Mystical Theology: The Integrity of Spirituality and Theology. Oxford: Blackwell, 1998.

Moody, A. David. Tracing T. S. Eliot's Spirit: Essays on His Poetry and Thought. Cambridge: Cambridge University Press, 1996.

Morris, Adalaide. How to Live/ What to Do: H.D. 'S Cultural Poetics. Urbana and Chicago: University of Illinois Press, 2003.

---. "Signaling: Feminism, Politics, and Mysticism in H.D.'s War Trilogy.” Sagetrieb 9.3 (1990): 121-33.

Murray, Paul. T. S. Eliot and Mysticism: The Secret History of Four Quartets. Basingstoke: MacMillan, 1991.

Ostriker, Alicia. Writing Like a Woman. Ann Arbor: The University of Michigan Press, 1983.

Pondrom, Cyrena N. "Trilogy and Four Quartets: Contrapuntal Visions of Spiritual Quest." Agenda 25.3-4 (1987): 155-65.

Sri, P. S. T. S. Eliot, Vedanta and Buddhism. Vancouver: University of British Columbia Press, 1985.

Tryphonopoulos, Demetres. "Introduction.” Majic Ring. Ed. Demtres Tryphonopoulos. Gainesville: University Press of Florida, 2009. xxi-xxxix.

---. The Celestial Tradition: A Study of Ezra Pound's the Cantos. Waterloo, Ontario: Wilfred Laurier University Press, 1992.

Turner, Denys. The Darkness of God: Negativity in Christian Mysticism. Cambridge: Cambridge University Press, 1995.

Tuveson, Ernest Lee. The Avatars of Thrice Great Hermes. London: Associated University Presses, 1982. 


\title{
Wolosky, Shira. Language Mysticism: The Negative Way of Language in Eliot, Beckett, and Celan. Stanford: Stanford University Press, 1995.
}

\begin{abstract}
${ }^{1}$ I gratefully acknowledge the support for this research provided by a Doctoral Award from the U.K. Arts and Humanities Research Council.

${ }^{2}$ Burnt Norton was published in 1935, while East Coker, The Dry Salvages and Little Gidding were published between 1940 and 1942. The three volumes of Trilogy, The Walls Do Not Fall, Tribute to the Angels and The Flowering of the Rod, were published in 1944, 1945 and 1946 respectively, although a handful of individual poems were published in Life and Letters Today in 1942. For publishing details and further discussion of the intertextual relationship between Four Quartets and Trilogy see Cyrena N. Pondrom, "Trilogy and Four Quartets: Contrapuntal Visions of Spiritual Quest," Agenda 25.3-4 (1987).
\end{abstract}

${ }^{3}$ I am not making a claim here for private reading or classroom practices, but the only criticism in English I have found that draws together the two poems is Cyrena N. Pondrom's article, referenced above, and Madelyn Detloff's work on modernism and mourning, see below.

${ }^{4}$ A brief bibliography of such criticism would include, in addition to those cited later in this paper, Helen Gardner, The Art of T. S. Eliot (London: The Cresset Press, 1949) 153-88; Eloise Knapp Hay, T. S. Eliot's Negative Way (London: Harvard University Press, 1982); Paul Murray, T. S. Eliot and Mysticism: The Secret History of Four Quartets (Basingstoke: MacMillan, 1991).

${ }^{5}$ References to Trilogy include volume, section and line number.

${ }^{6}$ Despite his commitment to Christian orthodoxy, Eliot also draws upon numerous religious traditions including Buddhism and Hinduism - to shape his poetry. However, the influence of Eastern religions on Four Quartets is outside the scope of this paper; my reading is inevitably partial. For readings of the sources and influences of Eastern religions on Four Quartets, see Paul Foster, The Golden Lotus: Buddhist Influence in T. S. Eliot's Four Quartets (Lewes, Sussex: The Book Guild, 1998); Cleo McNelly Kearns, T. S. Eliot and Indic Traditions: A Study in Poetry and Belief (Cambridge: Cambridge University Press, 1987) 230-66; P. S. Sri, T. S. Eliot, Vedanta and Buddhism (Vancouver: University of British Columbia Press, 1985).

${ }^{7}$ For further discussion of H.D.'s hermeticism see Dianne Chisholm, H.D. 's Freudian Poetics: Psychoanalysis in Translation (Ithaca, NY and London: Cornell University Press, 1992) 60-65; Susan Stanford Friedman, Psyche Reborn: The Emergence of H.D. (Bloomington: Indiana University Press, 1981) 184-228; Eileen Gregory, H.D. and Hellenism: Classic Lines (Cambridge: Cambridge University Press, 1997) 75-90; Timothy Materer, Modernist Alchemy: Poetry and the Occult (Ithaca and London: Cornell University Press, 1995); Adalaide Morris, How to Live/ What to Do: H.D. 's Cultural Poetics (Urbana and Chicago: University of Illinois Press, 2003) 110-17; Demetres Tryphonopoulos, "Introduction," Majic Ring, ed. Demtres Tryphonopoulos (Gainesville: University Press of Florida, 2009).

${ }^{8}$ Hermeticists frequently conflate the Greek Hermes with the Egyptian Thoth, who is also credited with inventing writing and judging the souls of the dead.

${ }^{9}$ Amy Hollywood, Sensible Ecstasy: Mysticism, Sexual Difference, and the Demands of History (Chicago and London: The University of Chicago Press, 2002) 13.

${ }^{10}$ In recent decades, feminist historians have noted that mysticism has been gendered in one of two ways; either it has been associated with femininity and denigrated, or distinctions have been drawn between positively valued, masculine-inflected mysticism that is intellectual and anti-visionary and a negatively valued, feminine mysticism that is associated with the body, emotion, eroticism and visions. Feminist scholars have generally responded to this distinction in two ways; either by accepting the gendered associations but reversing the valuation; or by rejecting or complicating this dichotomy, see Caroline Walker Bynum, Fragmentation and Redemption: Essays on Gender and the Human Body in Medieval Religion (New York: Zone Books, 1992); Amy Hollywood, The Soul as Virgin Wife: Mechthild of Magdeburg, Marguerite Porete and Meister Eckhart (Notre Dame and London: University of Notre Dame Press, 1995); Hollywood, Sensible Ecstasy; Grace Jantzen, Power, Gender and Christian Mysticism (Cambridge: Cambridge University Press, 1995). 
${ }^{11}$ Readers of Four Quartets have stressed the importance of silence in the poems: "the words are one part sound and three parts silence;" Denis Donoghue, “T. S. Eliot's Quartets: A New Reading (1965)," T. S. Eliot: A Selection of Critical Essays, ed. B. Bergonzi (London: 1969) 212.

${ }^{12}$ Mark A. McIntosh also argues for a progression from cataphasis to apophasis, which implicitly assumes the ultimacy of apophasis, but he does not consider the double negation and resulting instability of language described by Turner. Mark A. McIntosh, Mystical Theology: The Integrity of Spirituality and Theology (Oxford: Blackwell, 1998) 122-23.

${ }^{13}$ For an alternate view, which argues that both "ways" reflect the negative theology of John of the Cross, one the dark night of the senses (the route of the beginner) and the other the dark night of the soul (the more rare route of the advanced contemplative), see Hay, 153-56.

${ }^{14}$ Shira Wolosky, Language Mysticism: The Negative Way of Language in Eliot, Beckett, and Celan (Stanford: Stanford University Press, 1995) 25.

${ }^{15}$ Donoghue suggests that "every moment a new beginning" may be seen in the structure of Four Quartets as a whole, but he does not consider this as an approach to reading the particular moments within the poem; Donoghue, 213.

${ }^{16}$ Numerous Jewish and early Christian Biblical commentators located Paradise, or the Garden of Eden, on earth, with the Nile as one of its legendary rivers; Rita Nakashima Brock and Rebecca Ann Parker, Saving Paradise: How Christianity Traded Love of This World for Crucifixion and Empire (Boston: Beacon Press, 2008) 90-91.

${ }^{17}$ The importance of refusing to elide the distinction between history-as-freedom and history-as-servitude is underscored by the references to the Mississippi as "conveyor of commerce" and its "cargo of dead negroes" which emphasise its role in pre-bellum American traffic in slaves (Eliot 23, 27). 